\title{
DNA polymerasen protein expression predicts treatment response and survival of metastatic gastric adenocarcinoma patients treated with oxaliplatin-based chemotherapy
}

Kai-yuan Teng ${ }^{1,2+}$, Miao-zhen Qiu ${ }^{1,2+}$, Zhuang-hua Li ${ }^{1,2}$, Hui-yan Luo ${ }^{1,2}$, Zhao-lei Zeng ${ }^{1}$, Rong-zhen Luo ${ }^{1,3}$, Hui-zhong Zhang ${ }^{1,3}$, Zhi-qiang Wang ${ }^{1,2}$, Yu-hong Li ${ }^{1,2}$, Rui-hua Xu ${ }^{1,2^{*}}$

\begin{abstract}
Background: DNA polymerase $\eta(\mathrm{pol} \eta)$ is capable of bypassing DNA adducts produced by cisplatin or oxaliplatin and is associated with cellular tolerance to platinum. Previous studies showed that defective pol $\eta$ resulted in enhanced cisplatin or oxaliplatin sensitivity in some cell lines. The purpose of the present study was to investigate the role of pol $\eta$ protein expression in metastatic gastric adenocarcinoma.

Methods: Four gastric adenocarcinoma cell lines were chosen to explore the relationship between pol $\eta$ protein expression and oxaliplatin sensitivity by western blotting and MTT assay. Eighty metastatic gastric adenocarcinoma patients treated with FOLFOX or XELOX regimen as first-line chemotherapy were analyzed, corresponding pretreatment formalin-fixed paraffin-embedded tumor tissues were used to detect pol $\eta$ protein expression by immunohistochemistry. Relationship between pol $\eta$ protein expression and clinical features and outcome of these patients was analyzed.

Results: A positive linear relationship between pol $\eta$ protein expression and $48 \mathrm{~h}$ IC50 values of oxaliplatin in four gastric cancer cell lines was observed. Positivity of pol $\eta$ protein expression was strongly associated with poor treatment response, as well as shorter survival at both univariate ( 8 versus 14 months; $P<0.001$ ) and multivariate (hazard ratio, 4.555; 95\% confidence interval, 2.461-8.429; $\mathrm{P}<0.001$ ) analysis in eighty metastatic gastric adenocarcinoma patients.

Conclusions: Our study indicates that poln is a predictive factor of treatment response and survival of metastatic gastric adenocarcinoma patients treated with FOLFOX or XELOX as first-line chemotherapy. Therefore confirming the value of poln in studies with prospective design is mandatory.
\end{abstract}

\section{Background}

Stomach cancer is the fourth most common cancer worldwide, with 603,003 new cases among men and 330,290 new cases among women per year [1]. It is the second most common cause of cancer related death (700,000 deaths annually), with almost two-thirds of the cases occurring in developing countries and $42 \%$ in China alone [2]. Surgery remains the major potential

\footnotetext{
* Correspondence: xurh@sysucc.org.cn

† Contributed equally

'State Key Laboratory of Oncology in South China, Guangzhou 510060

China

Full list of author information is available at the end of the article
}

method to cure the disease; however, approximately $84 \%$ of gastric cancer patients will develop to be an advanced disease, with $30 \%$ of locally advanced cases, $30 \%$ metastatic diseases at diagnosis, and $24 \%$ recurrence diseases [3]. The literatures showed that the median survival was only 3-4 months among advanced gastric cancer patients without chemotherapy. The new generation of chemotherapeutic agents, such as Oxaliplatin, can prolong survival in advanced gastric cancer to be 10 to 12 months; moreover, chemotherapy can also improve the quality of life [4-12]. Therapeutic effect mainly depends on the response of drugs to tumor during the first-line 
chemotherapy, because so far only one small phase III study with 120 cases showed a modest survival benefit from irinotecan monotherapy over supportive care alone [13]. Unfortunately, due to drug resistance, only $30-50 \%$ response rates can be achieved even though administrating new generation drugs such as docetaxel, oxaliplatin, capecitabine, irinotecan, S1, etc to advanced gastric cancer patients as first-line treatment [3]. That means at least $50 \%$ patients have to undergo ineffective treatment, which may not only decrease the patients' quality of life, but also increase the economic burden. So how to predict response of chemotherapy agents in gastric cancer is a very important scientific issue.

Oxaliplatin is the third generation platinum, playing a vital role in chemotherapy for gastrointestinal cancer. Oxaliplatin-based combination regimen such as oxaliplatin plus 5-FU or 5-FU-like drug has been proven to be active in about 40-50\% of advanced gastric cancer patients [14-16]. Oxaliplatin and cisplatin share the similar mechanism, and cause mono-adducts and intra-strand or inter-strand cross-links in the double DNA helix that severely block DNA synthesis [17-19]. When this happens, some pathways of DNA damage repair may switch on, including nucleotide excision repair (NER), mismatch repair (MR), homologous recombination (HR), translesion DNA synthesis (TLS) [20]. These adduct repairs occur primarily through NER [21]. TLS is another alternative way to repair these lesions, which is mainly done by DNA polymerases $\eta$ [22]. Polymerase $($ Pol $\eta$, one of lesion-replicating enzymes, incorporates the correct nucleotide over lesions such as a platinum adduct by TLS and continues chain elongation, whereas classical pols cannot [23]. Poln has the highest efficacy of bypassing Pt-GG intra-strand diadducts caused by platinum among these lesion-replicating enzymes, with limited fidelity $[23,24]$. Recent experiments have shown that the absence of pol $\eta$ results in a statistically significant enhancement in cisplatin sensitivity when comparing polnnull Xeroderma Pigmentosum-variant human fibroblasts with pol $\eta$-expressing ones [25]. This enhancement is also observed when the cells were treated with carboplatin and oxaliplatin [25]. Recent data show that poln mRNA level negatively correlated with cisplatin sensitivity of non small cell lung cancer (NSCLC) cell lines [26].

In the present study, we report for the first time the relationship between pol $\eta$ protein expression and oxaliplatin sensitivity of gastric cancer cell lines and the significance of that in predicting treatment response and survival of metastatic gastric cancer patients treated with oxaliplatin-based chemotherapy.

\section{Materials and methods \\ Cell lines}

The gastric cancer cell lines, including SGC7901, AGS, MKN45, and MGC803, were donated by Professor
Libing Song from State Key Laboratory of Oncology in Southern China (Cancer Center of Sun yet-sen University). All cell lines were maintained in RPMI 1640 (Gibco) supplemented with $10 \%$ fetal bovine serum (Gibco), except MKN 45 with 20\% fetal bovine serum.

\section{Patients and Samples}

Patients in our clinical database with chemotherapynaïve, histologically proven metastatic advanced gastric cancer were enrolled for the study. All patients had to receive FOLFOX (fluorouracil, leucovorin and oxaliplatin) or XELOX (capecitabine and oxaliplatin) regimen as first-line chemotherapy at Cancer Center of Sun Yat-sen University, and formalin-fixed paraffin-embedded pretreatment samples under gastroscope biopsies or palliative operation were obtained. Histopathologic characteristics were confirmed by blinded review of the original pathology slides. The TNM classification was used for pathologic staging, and the World Health Organization classification was used for pathologic grading. Other inclusion criteria included age between 18-80, Eastern Cooperative Oncology Group (ECOG) performance status of 2 or less, second line chemotherapy or not, no radiation treatment. All patients provided written informed consent; we obtained separate consent for use of specimens. Study approval was obtained from independent ethics committees at Cancer Center of Sun Yat-Sen University. The study was undertaken in accordance with the ethical standards of the World Medical Association Declaration of Helsinki.

\section{Follow-up and evaluations}

Patients were followed up by telephone or letter communication once every year for a total of 4 years. Overall survival was defined as the time from the date of confirmed diagnosis to death and censored at the date of last contact for a surviving patient. Disease response was evaluated according to the Response Evaluation Criteria in Solid Tumours (RECIST criteria) [27].

\section{Cytotoxicity assays}

Cell growth inhibition was determined by $3-(4,5-$ dimethylthiazol-2-yl) -2,5-diphenyltetrazolium bromide assay (MTT assay). Briefly, cells were seeded in 96-well plates and allowed to attach overnight. After 48 hours of drug incubation at various concentrations $\left(37^{\circ} \mathrm{C}\right)$, MTT reagent $(5 \mathrm{mg} / \mathrm{mL}, 20 \mu \mathrm{L} /$ well $)$ was added to each well and incubated for an additional 4 hours. The plates were then centrifuged (1,500 g, 5 minutes) and the supernatant was removed. The cell pellets were dissolved in $200 \mathrm{uL}$ DMSO. Absorbance was determined using the Model 550 Microplate Reader (BIO-RAD, Hercules, CA, USA) at a wavelength of $570 \mathrm{~nm}$, with background subtraction at a wavelength of $630 \mathrm{~nm}$. All 
experiments were performed in triplicate. The concentration required to inhibit cell growth by $50 \%$ (IC50) was calculated from survival curves using the Bliss method [28].

\section{Western blotting}

Cells were washed with ice-cold phosphate buffer saline and harvested in sampling buffer $[62.5 \mathrm{mmol} / \mathrm{L}$ Tris$\mathrm{HCl}$ (pH 6.8), 2\% SDS, 10\% glycerol, and 5\% 2-h-mercaptoethanol]. Protein concentration was determined by Bradford assay (Bio-Rad Laboratories). Equal amounts of proteins were applied to $7.5 \%$ polyacrylamide SDS gels (SDS-PAGE), separated electrophoretically, and transferred onto polyvinylidene fluoride membranes. After blocked in $5 \%$ non-fat milk in TBST buffer $(10 \mathrm{mmol} / \mathrm{L}$ Tris-HCL, $150 \mathrm{mmol} / \mathrm{L} \mathrm{NaCl}$, and $0.1 \%$ Tween $20, \mathrm{pH}$ 8.0) for $1 \mathrm{~h}$ at room temperature, the membrane was incubated with anti-pol $\eta$ rabbit antibody (1:400; Abcam). Pol $\eta$ expression was detected with horseradish peroxidase-conjugated goat anti-rabbit IgG and enhanced chemiluminescence. Anti- $\alpha$-tubulin antibody was used as the loading control.

ImageJ software from National Institutes of Health (NIH) was employed to quantify protein.

\section{Immunohistochemistry}

Immunohistochemical (IHC) analysis was done to detect polnprotein expression in 80 human gastric cancer tissues. Briefly, the tissue sections were deparaffinized in xylene at $37^{\circ} \mathrm{C}$ for 20 minutes and rehydrated. Endogenous peroxide was blocked by incubating the sections with $3 \%$ hydrogen peroxide in methanol for 20 minutes at $37^{\circ} \mathrm{C}$. Then the sections were submerged into $10 \mathrm{mM}$ citrate buffer $(\mathrm{pH} \mathrm{6.0)}$ and microwaved for antigenic retrieval, followed by incubation with rabbit anti- poln (1:100; Abcam) overnight at $4^{\circ} \mathrm{C}$. After washing, tissue sections were treated with horseradish peroxidaselabeled secondary antibody for 30 minutes. The sections were developed with diaminobenzidine tetrahydrochloride (DAB) and counterstained with hematoxylin.

Analysis of immunohistochemistry in our study was carried out by two independent observers based on the proportion of positively stained tumor cells. If there is difference between these two observers, these slides were reinvestigated by both investigators using a multiheaded microscope. Tumors with more than $5 \%$ of POL $\eta$-positive cancer cells were regarded as positive (nucleus staining), otherwise negative.

\section{Statistical analysis}

Receiver operating characteristic (ROC) curve analysis and Fisher's exact test were performed to select IHC Polpositive value with highest accuracy. $2 \times 2$ table was constructed yielding sensitivity, specificity, positive and negative predictive value, and accuracy was calculated as proportion of true positive and true negative patients out of whole patients. All statistical analyses were performed by SPSS 15.0 statistical software package (SPSS Inc, Chicago, IL, USA). P value $<0.05$ was considered to be statistically significant. Kaplan-Meier analysis with log-rank testing was used for univariate analyses. Variables showing a trend for association with survival $(\mathrm{P}<0.05)$ were selected for inclusion in the final multivariate Cox proportional hazards model. The relationship between pol $\eta$ expression and clinicopathologic characteristics was examined by a chi-square test and Fisher's exact tests.

\section{Results}

Poln expression correlates with oxaliplatin sensitivity of gastric cancer cell lines

Oxaliplatin sensitivity of four gastric cell lines (SGC7901, AGS, MKN45, and MGC803) were detected by MTT assay described above. Endogenous poln protein expression of four cell lines were compared with each other by western blotting and the half maximal inhibitory concentration (IC50) values of oxaliplatin for cells were shown in Figure 1. Significant and positive correlation was observed, as shown in Figure 2 when compared pol $\eta$ protein expression with IC50 values of oxaliplatin.

\section{Patient characteristics}

Eighty patients from January 2005 and July 2009 were retrospectively analyzed. Patients had a median age of 54 (range, 26.0-79.0), with 49 males and 31 females. Other clinical characteristics were summarized in Table 1. The response rate $(\mathrm{CR}+\mathrm{PR})$ with first-line XELOX or FOLFOX chemotherapy was $47.5 \%$, clinical benefit rate $(\mathrm{CR}+\mathrm{PR}+\mathrm{SD})$ was $77.5 \%$. Part of these patients $(23 / 80)$ had second-line chemotherapy.

The criteria that tumor tissue with more than $5 \%$ of Polnpositive cancer cells was defined as IHC-positive has highest accuracy in predicting clinical benefit of first line chemotherapy

Tumor tissues of eighty metastatic gastric cancer patients treated with FOLFOX or XELOX regimen were used to detect pol $\eta$ protein expression by Immunohistochemistry (Figure 3 ). Because the percentage of nucleusstaining tumor cells in all cases was no more than $10 \%$, we tried to select IHC Poln-positive value with highest accuracy to predict clinical benefit of first line chemotherapy. We defined nine IHC-positive value: $\geq 1 \%$, $\geq$ $2 \%, \geq 3 \%, \geq 4 \%, \geq 5 \%, \geq 6 \%, \geq 7 \%, \geq 8 \%, \geq 9 \%$, and constructed nine $2 \times 2$ table. Table 2 is showed as an example. Sensitivity, specificity, positive and negative predictive value, and accuracy was calculated and used to draw ROC curve. As showed in Table 3 and Figure 4 cut off value $\geq 5 \%$, has highest accuracy $(88.8 \%)$. So 


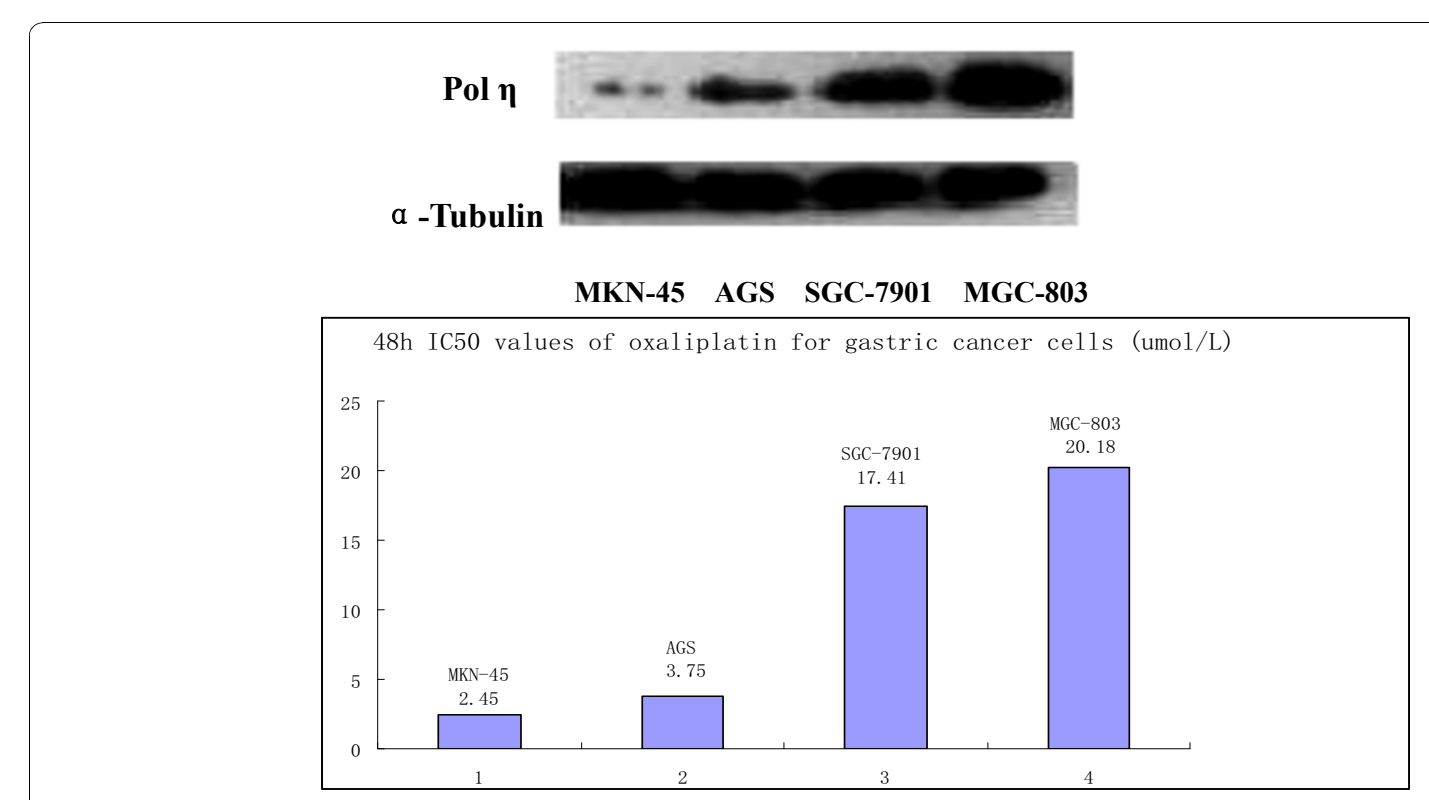

Figure 1 Expression analysis of POL $\eta$ protein in gastric cancer cell lines by western blotting and $48 \mathrm{~h}$ IC50 values of oxaliplatin for gastric cancer cells (umol/L).

tumors with more than $5 \%$ of POL $\eta$-positive cancer cells were regarded as positive (nucleus staining), otherwise negative.

\section{Relationship of poln expression with the clinical features} of metastatic gastric cancer

As shown in Table 4 Only 23 of 80 cases $(28.75 \%)$ had pol $\eta$ protein positive expression $(\geq 5 \%$ Pol $\eta$-positive cancer cells), 16 of the 23 positive cases (69.56\%) failed to the treatment, in contrast, only 2 of the 57 negative cases (3.51\%) had progressed disease after FOLFOX or XELOX chemotherapy. Pol $\eta$ expression strongly correlated with treatment response to oxaliplatin-based chemotherapy of metastatic gastric cancer $(P<0.001)$, whereas it is not associated with age, gender, primary sites, metastatic sites or pathologic differentiation levels.

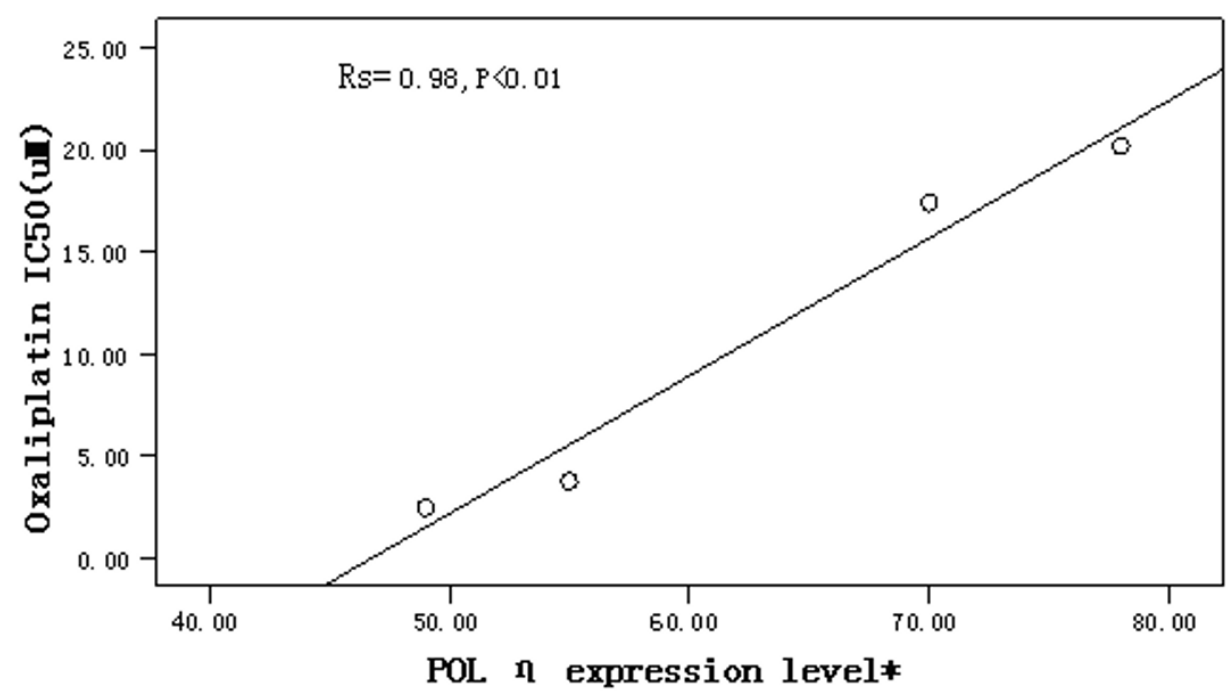

*Pol $\eta$ expression level was estimated by ImageJ software. $X$ axis represents grey scale of pol \ lanes on the westem blotting film.Rs is Spearman rank test.

Figure 2 Correlation between POL $\eta$ expression and IC50 of oxaliplatin for gastric cells. 
Table 1 Patient characteristics $(\mathbf{N}=\mathbf{8 0})$

\begin{tabular}{|c|c|c|}
\hline characteristic & No. of patients & $\%$ \\
\hline \multicolumn{3}{|l|}{ Age(yrs) } \\
\hline Median & 54.0 & \\
\hline Range & $26.0-79.0$ & \\
\hline \multicolumn{3}{|l|}{ Sex } \\
\hline Male & 49 & 61.3 \\
\hline Female & 31 & 38.7 \\
\hline \multicolumn{3}{|c|}{ ECOG performance status } \\
\hline 0 & 36 & 45.0 \\
\hline 1 & 42 & 52.5 \\
\hline 2 & 2 & 2.5 \\
\hline \multicolumn{3}{|l|}{ Primary sites } \\
\hline Cardia & 21 & 26.3 \\
\hline Body & 18 & 22.5 \\
\hline Antrum/pylorus & 41 & 51.2 \\
\hline \multicolumn{3}{|l|}{ Metastatic sites } \\
\hline Liver & 26 & 32.5 \\
\hline Lung & 21 & 26.3 \\
\hline Peritoneum & 19 & 23.8 \\
\hline Others & 14 & 17.4 \\
\hline \multicolumn{3}{|c|}{ Pathologic differentiation NO } \\
\hline G1 & 2 & 2.5 \\
\hline G2 & 26 & 32.5 \\
\hline G3 & 52 & 65.0 \\
\hline \multicolumn{3}{|c|}{ Treatment Response (1st line) } \\
\hline$C R$ & 2 & 2.5 \\
\hline PR & 36 & 45.0 \\
\hline SD & 24 & 30.0 \\
\hline PD & 18 & 22.5 \\
\hline \multicolumn{3}{|c|}{$2^{\text {nd }}-$ line chemotherary regimen } \\
\hline BSC & 57 & 71.3 \\
\hline FOLFIRI & 6 & 7.5 \\
\hline XELIRI & 8 & 10.0 \\
\hline DX & 6 & 7.5 \\
\hline $\mathrm{TP}$ & 3 & 3.7 \\
\hline
\end{tabular}

$\mathrm{CR}$, complete response; $\mathrm{PR}$, partial response; $\mathrm{SD}$, stable disease; $\mathrm{PD}$, progression disease;

BSC, best supportive care; FOLFIRI, 5-fluracil plus leucovorin plus irinotecan; XELIRI, capecitabine plus irinotecan; DX, docitaxel plus capecitabine; TP, paclitaxel plus cisplatin.

Spearman correlation analysis was further done to confirm the correlation between pol $\eta$ expression and clinicopathologic features. Pearson contingency coefficient shown that polnexpression levels was significantly related with treatment response $(\mathrm{P}<0.001)$, likewise, no significant correlations with other factors was obtained (data not shown).

\section{Relationship between pol $\eta$ expression and survival of metastatic gastric cancer}

Kaplan-Meier univariate survival analysis revealed that the positive expression of pol $\eta$ in tumor cells and poor treatment response were significantly associated with shorter survival. The median survival time for pol $\eta$ positive and negative cases were 8 and 14 months respectively, as shown in Figure 5 (log rank, $\mathrm{P}<0.001)$. Multivariate survival analysis (Cox regression model) revealed that the expression of pol $\eta$ was independent prognostic factors. The $95.0 \%$ confidence interval (CI) for relative risk was 2.461-8.429 (Table 5). These results indicated that the expression of poln in tumor tissue predicted shorter survival. No relationship was observed between the survival and the rest clinicopathological parameters such as age, gender, primary tumor sites, pathologic differentiation and metastatic sites.

\section{Discussion}

The present study partially revealed the role of DNA polymerasen as a DNA repair protein in gastric cancer by detecting its expression in four gastric cancer cell lines and 80 patients with metastatic gastric adenocarcinoma who had received FOLFOX or XELOX as the first line chemotherapy. The results showed that the expression level of poln in tumor cell lines was correlated with the sensitivity of oxaliplatin (Figure 2). For the tumor tissue, the positive expression only occurred in $28.75 \%$ cases (23 out of 80 ), and the expression was modest. However, strong correlation was found between poln expression and treatment response as well as survival. All the results demonstrated that pol $\eta$ positivity was an indicator for poor treatment response and shorter survival in patients of above settings.

DNA polymerasen is coded by POLH gene which is one of the 150 human DNA repair genes, whose defection results in Xeroderma Pigmentosum Variant (XP-V) syndrome, manifesting highly sensitivity to UV radiation and a trend to develop skin cancer [29-31]. Pol $\eta$ is an important lesion-replicating enzyme that replicates across pyrimidine dimers introduced by UV radiation, avoiding high gene mutation [32]. In addition to pyrimidine dimers, poln has been shown to replicate across cisplatin cross-linked intrastrand GG sites [33]. Some researches showed that poln expression was correlated with sensitivity to cisplatin or oxaliplatin in XP-V human fibroblasts cell and lung cell lines, and pol $\eta$ seemed to be a treatment-response predictive marker in NSCLC patients with cisplatin-based chemotherapy [26,27].

Less is known about the role of pol $\eta$ in gastric cancer. It is the first study to detect the sensitivity of oxaliplatin in these four gastric carcinoma cell lines (SGC7901, AGS, MKN45, and MGC803) by MTT assay and protein expression by western blotting. We found a significant linear relationship between them. Our study was to some extent consistent with the observation in lung cancer cell lines by Paolo Ceppi et al, though what they detected were poln mRNA level and cisplatin sensitivity [27]. 


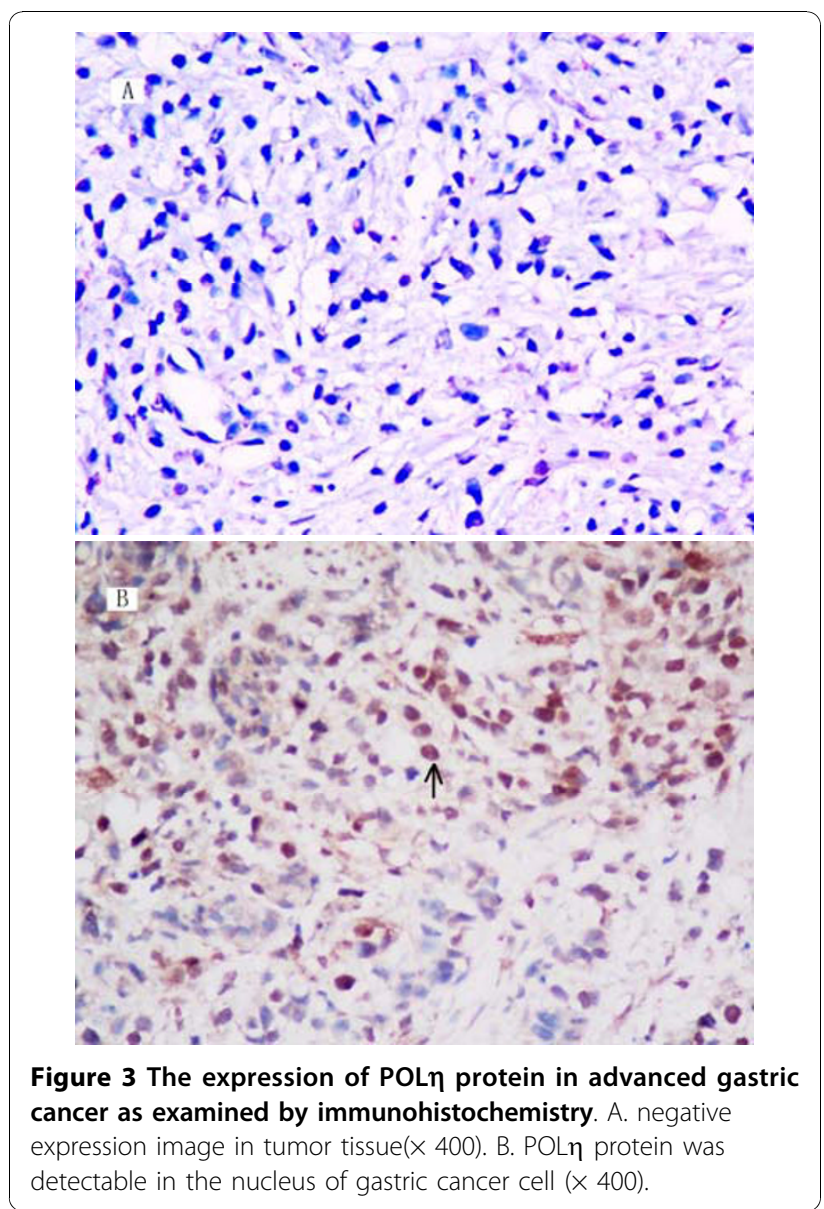

Table 2 DNA polymerase $\eta$ protein expression and clinical treatment response

\begin{tabular}{llll}
\hline & Clinical failure & Clinical benefit & Total cases \\
\hline Pol $\eta(+)$ & 16 & 7 & 23 \\
Pol $\eta(-)$ & 2 & 55 & 57 \\
Total cases & 18 & 62 & 80 \\
\hline
\end{tabular}

$\geq 5 \%$ Poln expression in tumor cells defined as positive.

Table 3 Accuracy, sensitivity, specificity, positive predictive value, and negative predictive value according to Poln IHC counting percent in predicting chemotherapy response to FOLFOX or XELOX regimen

Tumor cell positive Specificity Sensitivity PPV NPV Accuracy percent, cut off

\begin{tabular}{llllll}
\hline$\%$ & 0.419 & 0.889 & 0.308 & 0.929 & 0.525 \\
$2 \%$ & 0.500 & 0.889 & 0.340 & 0.940 & 0.588 \\
$3 \%$ & 0.645 & 0.889 & 0.421 & 0.952 & 0.700 \\
$4 \%$ & 0.823 & 0.889 & 0.593 & 0.962 & 0.838 \\
$5 \%$ & 0.887 & 0.889 & 0.696 & 0.965 & 0.888 \\
$6 \%$ & 0.887 & 0.778 & 0.667 & 0.932 & 0.863 \\
$7 \%$ & 0.978 & 0.667 & 0.705 & 0.904 & 0.863 \\
$8 \%$ & 0 & 0.389 & 1.000 & 0.849 & 0.863 \\
$9 \%$ & 0 & 0.111 & 1.000 & 0.795 & 0.800 \\
\hline
\end{tabular}

PPV, positive predictive value; NPV, negative predictive value.

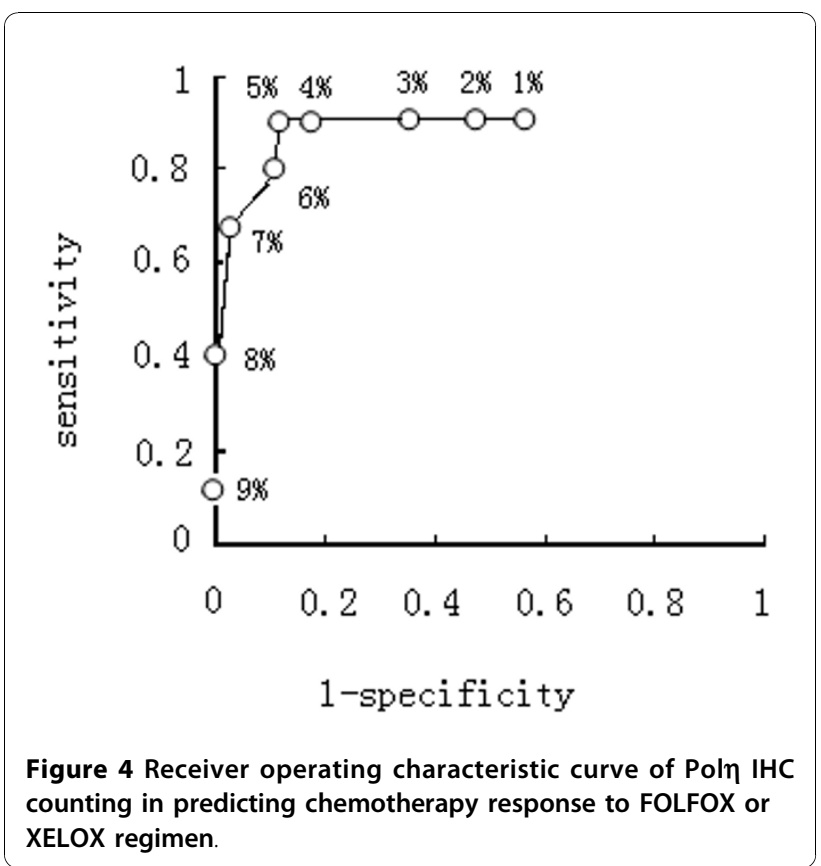

Table 4 Correlation between POL $\eta$ expression and clinicopathologic characteristics of gastric cancer patients POL $\eta$

\begin{tabular}{|c|c|c|c|c|}
\hline characteristic & $\begin{array}{l}\text { Positive } \\
(n=23)\end{array}$ & $\begin{array}{l}\text { Negative } \\
(\mathrm{n}=57)\end{array}$ & $\begin{array}{l}\chi^{2} \text { test } \\
\text { P value }\end{array}$ & $\begin{array}{l}\text { Fisher's test } \\
P \text { value }\end{array}$ \\
\hline \multicolumn{5}{|l|}{ Age(y) } \\
\hline$<60$ & 16 & 37 & 0.690 & 0.797 \\
\hline$\geq 60$ & 7 & 20 & & \\
\hline \multicolumn{5}{|l|}{ Gender } \\
\hline Male & 14 & 35 & 0.695 & 1.000 \\
\hline Female & 9 & 22 & & \\
\hline \multicolumn{5}{|l|}{ Primary sites } \\
\hline Cardia & 10 & 11 & 0.084 & 0.102 \\
\hline Body & 4 & 14 & & \\
\hline Antrum/pylorus & 9 & 32 & & \\
\hline \multicolumn{5}{|l|}{ Metastatic sites } \\
\hline Liver & 11 & 15 & 0.247 & 0.269 \\
\hline Lung & 5 & 16 & & \\
\hline Peritoneum & 3 & 16 & & \\
\hline Others & 4 & 10 & & \\
\hline \multicolumn{5}{|c|}{ Pathologic differentiation } \\
\hline G1 & 2 & 0 & 0.068 & 0.107 \\
\hline G2 & 6 & 20 & & \\
\hline G3 & 15 & 37 & & \\
\hline \multicolumn{5}{|l|}{ Treatment Response } \\
\hline $\mathrm{CR}+\mathrm{PR}+\mathrm{SD}$ & 7 & 55 & $<0.001$ & $<0.001$ \\
\hline PD & 16 & 2 & & \\
\hline
\end{tabular}

$\mathrm{CR}$, complete response; $\mathrm{PR}$, partial response; $\mathrm{SD}$, stable disease; $\mathrm{PD}$, progression disease. 


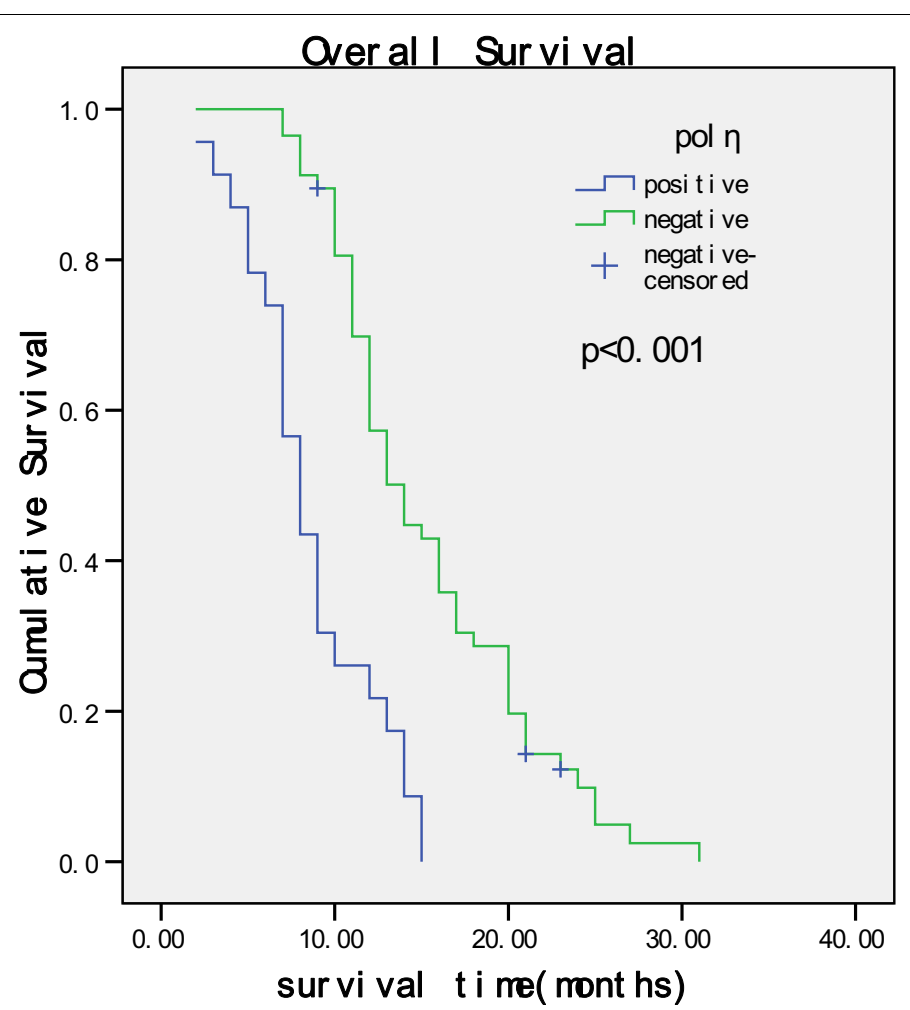

Figure 5 Kaplan-Meier curves with univariate analysis (log-rank test) for patients with negative POL $\eta$ expression versus positive POL $\eta$ expression tumors.

Then we restrospectively analyzed the expression of pol $\eta$ protein in eighty metastatic advanced gastric cancer patients who received FOLFOX or XELOX as chemotherapy. We firstly observed that the percentage of poln-staining tumor cells in all 80 cases was no more than $10 \%$, so we defined $\geq 5 \%$ as IHC positive according to the accuracy in predicting clinical benefit with XELOX or FOLFOX chemotherapy. With this standard, only 23 patients had positive expression, with 7 out of 62 clinical benefit cases $(\mathrm{CR}+\mathrm{PR}+\mathrm{SD})$ from chemotherapy and 16 out of $18 \mathrm{PD}$ cases. The expression rate between clinical benefit group $(7 / 62,11.3 \%)$ and PD group $(16 / 18,88.9 \%)$ was significantly different $(\mathrm{P}<$ $0.001)$. This indicated that Pol $\eta$ positivity might predict ineffective chemotherapy with XELOX or FOLFOX regimen. The result was consistent with our study in cells that Pol $\eta$ expression negatively correlates with oxaliplatin sensitivity of gastric cancer cell lines.

We found a significant survival benefit in pol $\eta$ negative patients. This benefit probably came from effective therapy of oxaliplatin, given that pol $\eta$ was strongly correlated with treatment response. It is well known that effective chemotherapy would enhance life quality of gastric cancer patients and improve survival; our investigation can help to predict the treatment response of oxaliplatin-based chemotherapy and survival, hence avoid unnecessary treatment at the beginning.

There are several limitations to our study. First, This is a retrospective study with a small number of patients. In the preset study, no significant association between pol $\eta$ expression and age, gender, primary tumor sites, metastatic sites or pathologic differentiation was

Table 5 Multivariate analysis of overall survival in gastric carcinoma

\begin{tabular}{|c|c|c|c|c|c|}
\hline \multirow[t]{2}{*}{ Factors } & \multicolumn{2}{|c|}{ Characteristics } & \multirow[t]{2}{*}{ Hazard ratio } & \multirow[t]{2}{*}{$95 \% \mathrm{Cl}$} & \multirow[t]{2}{*}{$P$ value } \\
\hline & Unfavorable & Favorable & & & \\
\hline Age & $\geq 60$ & $<60$ & 0.956 & $0.570-1.602$ & 0.863 \\
\hline Histological grade & Poorly & Well/moderately & 1.428 & $0.861-2.369$ & 0.168 \\
\hline POL $\eta$ & positive & negative & 4.555 & $2.461-8.429$ & $<0.001$ \\
\hline
\end{tabular}

$\mathrm{Cl}$, confidence interval. 
obtained on the basis of such cases number. It is possible to get significant results in some clinicopathologic characteristics such as primary sites or pathologic differentiation ( $\mathrm{P}$ value close to 0.05 ), if with enough patients. Therefore enlargeing the case number and performing prospective trials is mandatory. Second, because the test accuracy was calculated using the criteria defined by ROC curve analysis, our results needed validation in an independent cohort. Third, the expression of pol $\eta$ is relatively low in gastric cancer, due to subjectivity, the error of IHC counting could be bigger, which may influence the sensitivity and specificity when predicting treatment response, so more accurate method is needed. Forth, It is well known that platinum resistance is very complicated, so pol $\eta$, as a single parameter, is hard to predict therapy response in an exact manner.

In spite of limitations, our study is one of the few attempts to define criteria for in vivo chemosensitivity of oxaliplatin-containing regimen using clinical response as reference standard. It may be an effective and costsaving method to predict treatment response.

\section{Conclusion}

In conclusion, the present study demonstrated that poln is a significant predictor of treatment response in patients with metastatic gastric cancer receiving chemotherapy of FOLFOX or XELOX. Such a marker might help clinicians to choose the optimal clinical strategy for patients with advanced gastric cancer. Moreover, the multivariate survival analysis revealed that the expression of pol $\eta$ was independent prognostic factors. The findings need to be confirmed in a larger prospective trial before application in clinical practice.

\section{Abbreviations \\ GG: guanine-guanine; CR: complete response; DNA: deoxyribonucleic acid; FOLFOX: fluorouracil, leucovorin and oxaliplatin; HR: homologous Recombination; mRNA; messenger ribonucleic acid; IC50: the half inhibitory concentration; IHC: immunohistochemistry; MMR: mismatch Repair; WB: western blotting; MTT assay: 3- (4,5-dimethylthiazol-2-yl) -2,5- diphenyltetrazolium bromide assay; NER: nucleotide Excision Repair; OS: overall survival; PD: progression disease; Pol $\eta$ : polymerase eta; PR: partial response; SD: stable disease; Pt: platinum; ROC: receiver operating characteristic; TLS: translesion synthesis; XELOX: capecitabine and oxaliplatin; XPV: xeroderma pigmentosum variant.}

\section{Acknowledgements}

We thank the staff members in the Department of Medical Oncology at Sun Yat-sen University Cancer Center for their suggestion and assistance. Grant support: National Natural Science Foundation of China grant 30672408, Guangzhou Bureau of Science and Technology grant 2006Z3E0041 and Sun Yat-sen University 985 Program Initiation Fund (China).

\section{Author details}

'State Key Laboratory of Oncology in South China, Guangzhou 510060, China. ${ }^{2}$ Department of Medical Oncology, Sun Yat-Sen University Cancer Center, Guangzhou 510060, China. ${ }^{3}$ Department of Pathology, Sun Yat-Sen University Cancer Center, Guangzhou 510060, China.

\section{Authors' contributions}

KYT carried out the cytotoxicity assay and the $\mathrm{IHC}$, participated in the clinica data collecting of the gastric carcinoma patients and drafted the manuscript. MZQ participated in the clinical data collecting and drafted the manuscript. ZHL carried out the cytotoxicity assay. HYL performed the statistical analysis. ZLZ participated in the design of the study. RZL and HZZ reviewed the IHC slices. ZQW and YHL participated in the statistical analysis. RHX conceived of the study, and participated in its design and coordination and helped to draft the manuscript. All authors read and approved the final manuscript.

\section{Competing interests}

We have no financial or personal relationships with other people or organizations that would bias our work. No benefits in any form have been received or will be received from a commercial party related directly or indirectly to the subject of our article.

Received: 9 August 2010 Accepted: 27 November 2010

Published: 27 November 2010

\section{References}

1. Kamangar F, Dores GM, Anderson WF: Patterns of cancer incidence, mortality, and prevalence across five continents: defining priorities to reduce cancer disparities in different geographic regions of the world. $J$ Clin Oncol 2006, 24:2137-50.

2. Parkin DM, Bray F, Ferlay J, Pisani P: Global Cancer Statistics, 2002. CA Cancer J Clin 2005, 55:74-108.

3. Rivera F, Vega-Villegas ME, López-Brea MF: Chemotherapy of advanced gastric cancer. Cancer Treat Rev 2007, 33:315-24.

4. Murad AM, Santiago FF, Petroianu A, Rocha PR, Rodrigues MA, Rausch M: Modified therapy with 5-fluorouracil, doxorubicin, and methotrexate in advanced gastric cancer. Cancer 1993, 72:37-41.

5. Pyrhönen $S$, Kuitunen $T$, Nyandoto $P$, Kouri M: Randomised comparison of fluorouracil, epidoxorubicin and methotrexate(FEMTX) plus supportive care with supportive care alone in patients with non-resectable gastric cancer. Br J Cancer 1995, 71:587-91.

6. Glimelius B, Ekström K, Hoffman K, Graf W, Sjödén PO, Haglund U, Svensson C, Enander LK, Linné T, Sellström H, Heuman R: Randomized comparison between chemotherapy plus best supportive care with best supportive care in advanced gastric cancer. Ann Oncol 1997, 8:163-8.

7. Bouché O, Raoul JL, Bonnetain F, Giovannini M, Etienne PL, Lledo G, Arsène D, Paitel JF, Guérin-Meyer V, Mitry E, Buecher B, Kaminsky MC, Seitz JF, Rougier P, Bedenne L, Milan C: Randomized multicenter phase II trial of a biweekly regimen of fluorouracil and leucovorin (LV5FU2), LV5FU2 plus cisplatin, or LV5FU2 plus irinotecan in patients with previously untreated metastatic gastric cancer: a Federation Francophone de Cancerologie Digestive Group Study -FFCD 9803. J Clin Oncol 2004, 22:4319-28.

8. Van Cutsem E, Moiseyenko VM, Tjulandin S, Majlis A, Constenla M, Boni C, Rodrigues A, Fodor M, Chao Y, Voznyi E, Risse ML, Ajani JA: Phase III study of docetaxel and cisplatin plus fluorouracil compared with cisplatin and fluorouracil as first line therapy for advanced gastric cancer: a report of the V-325 Study Group. J Clin Oncol 2006, 24:4991-7.

9. Pinto C, Di Fabio F, Siena S, Cascinu S, Rojas Llimpe FL, Ceccarelli C, Mutri V, Giannetta L, Giaquinta S, Funaioli C, Berardi R, Longobardi C, Piana E, Martoni AA: Phase II study of cetuximab in combination with FOLFIRI in patients with untreated advanced gastric or gastroesophageal junction adenocarcinoma (FOLCETUX study). Ann Oncol 2007, 18:510-7.

10. Boku N, Yamamoto S, Shirao K, Doi T, Sawaki A, Koizumi W, Saito H, Yamaguchi K, Kimura A, Ohtsu A: Randomized phase III study of 5fluorouracil (5-FU) alone versus combination of irinotecan and cisplatin (CP) versus S-1 alone in advanced gastric cancer (JCOG9912). ASCO Meeting Abstracts 2007, 4513.

11. Cunningham D, Starling N, Rao S, Iveson T, Nicolson M, Coxon F, Middleton G, Daniel F, Oates J, Norman AR: Capecitabine and oxaliplatin for advanced esophagogastric cancer. N Engl J Med 2008, 358:36-46.

12. Kang HJ, Chang HM, Kim TW, Ryu MH, Sohn HJ, Yook JH, Oh ST, Kim BS, Lee JS, Kang YK: A phase II study of paclitaxel and capecitabine as a firstline combination chemotherapy for advanced gastric cancer. $\mathrm{Br} J$ Cancer 2008, 98:316-22.

13. Thuss-Patience P, Kretzschmar A, Deist T, Hinke A, Bichev D, Lebedinzew B, Gebauer B, Schumacher G, Reichardt P: Survial advantage for irinotecan 
versus best supportive care (BSC) as 2nd-line chemotherapy in gastric cancer-a randomised phase III study of the Arbeitsgemeinschaft Internistische Onkologie (AIO). ECCO15-ESMO34 2009, Abstract O-6504.

14. Zhao JG, Qiu F, Xiong JP, Zhang L, Xiang XJ, Yu F, Yan J, Zhan ZY, Feng M: A phase II study of modified FOLFOX as first-line chemotherapy in elderly patients with advanced gastric cancer. Anticancer Drugs 2009, 20:281-6.

15. Keam B, Im SA, Han SW, Ham HS, Kim MA, Oh DY, Lee SH, Kim JH, Kim DW, Kim TY, Heo DS, Kim WH, Bang YJ: Modified FOLFOX-6 chemotherapy in advanced gastric cancer: Results of phase II study and comprehensive analysis of polymorphisms as a predictive and prognostic marker. BMC Cancer 2008, 8:148.

16. Liu ZF, Guo QS, Zhang XQ, Yang XG, Guan F, Fu Z, Wang MY: Biweekly oxaliplatin in combination with continuous infusional 5-fluorouracil and leucovorin (modified FOLFOX-4 regimen) as first-line chemotherapy for elderly patients with advanced gastric cancer. Am J Clin Oncol 2008, 31:259-63.

17. Lawley PD, Phillips DH: DNA adducts from chemotherapeutic agents. Mutat Res 1996, 355:13-40.

18. Woynarowski JM, Chapman WG, Napier C, Herzig MC, Juniewicz P. Sequence- and region-specificity of oxaliplatin adducts in naked and cellular DNA. Mol Pharmacol 1998, 54:770-7.

19. Woynarowski JM, Faivre S, Herzig MC, Arnett B, Chapman WG, Trevino AV, Raymond E, Chaney SG, Vaisman A, Varchenko M, Juniewicz PE: Oxaliplatininduced damage of cellular DNA. Mol Pharmacol 2000, 58:920-7.

20. Rabik CA, Dolan ME: Molecular mechanisms of resistance and toxicity associated with platinating agents. Cancer Treat Rev 2007, 33:9-23.

21. Zamble DB, Mu D, Reardon JT, Sancar A, Lippard SJ: Repair of cisplatinDNA adducts by the mammalian excision nuclease. Biochemistry 1996, 35:10004-13

22. Levine RL, Miller H, Grollman A, Ohashi E, Ohmori H, Masutani C, Hanaoka F, Moriya M: Translesion DNA synthesis catalyzed by human pol eta and pol kappa across 1, N6-ethenodeoxyadenosine. J Biol Chem 2001, 276:18717-21.

23. Vaisman A, Masutani C, Hanaoka F, Chaney SG: Efficient translesion replication past oxaliplatin and cisplatin GpG adducts by human DNA polymerase eta. Biochemistry 2000, 39:4575-80.

24. Matsuda T, Bebenek K, Masutani C, Hanaoka F, Kunkel TA: Low fidelity DNA synthesis by human DNA polymerase eta. Nature 2000, 404:1011-3.

25. Albertella MR, Green CM, Lehmann AR, O'Connor MJ: A role for polymerase eta in the cellular tolerance to cisplatin-induced damage. Cancer Res 2005, 65:9799-806.

26. Ceppi P, Novello S, Cambieri A, Longo M, Monica V, Lo lacono M, GiajLevra M, Saviozzi S, Volante M, Papotti M, Scagliotti G: Polymerase eta mRNA expression predicts survival of non-small cell lung cancer patients treated with platinum-based chemotherapy. Clin Cancer Res 2009, 15:1039-45.

27. Eisenhauer EA, Therasse P, Bogaerts J, Schwartz LH, Sargent D, Ford R, Dancey J, Arbuck S, Gwyther S, Mooney M, Rubinstein L, Shankar L, Dodd L, Kaplan R, Lacombe D, Verweij J: New response evaluation criteria in solid tumours: revised RECIST guideline (version 1.1). Eur J Cancer 2009, 45:228-47.

28. Shi Z, Liang YJ, Chen ZS, Wang XW, Wang XH, Ding Y, Chen LM, Yang XP, Fu LW: Reversal of MDR1/P-glycoprotein-mediated multidrug resistance by vector-based RNA interference in vitro and in vivo. Cancer Biol Ther 2006, 5:39-47.

29. Masutani C, Kusumoto R, Yamada A, Dohmae N, Yokoi M, Yuasa M, Araki M, Iwai S, Takio K, Hanaoka F: The XPV (xeroderma pigmentosum variant) gene encodes human DNA polymerase eta. Nature 1999, 399:700-4.

30. Masutani C, Araki M, Yamada A, Kusumoto R, Nogimori T, Maekawa T, Iwai S, Hanaoka F: Xeroderma pigmentosum variant (XP-V) correcting protein from HeLa cells has a thymine dimer bypass DNA polymerase activity. EMBO J 1999, 18:3491-501.

31. Cleaver JE, Arutyunyan RM, Sarkisian T, Kaufmann WK, Greene AE, Coriell L: Similar defects in DNA repair and replication in the pigmented xerodermoid and the xeroderma pigmentosum variants. Carcinogenesis 1980, 1:647-55.

32. Wang YC, Maher VM, Mitchell DL, McCormick JJ: Evidence from mutation spectra that the UV hypermutability of xeroderma pigmentosum variant cells reflects abnormal, error-prone replication on a template containing photoproducts. Mol Cell Biol 1993, 13:4276-83.
33. Lehmann AR: Replication of damaged DNA in mammalian cells: New solutions to an old problem. Mutat Res 2002, 509:23-34.

doi:10.1186/1479-5876-8-126

Cite this article as: Teng et al:: DNA polymerasen protein expression predicts treatment response and survival of metastatic gastric adenocarcinoma patients treated with oxaliplatin-based chemotherapy. Journal of Translational Medicine 2010 8:126.

\section{Submit your next manuscript to BioMed Central and take full advantage of:}

- Convenient online submission

- Thorough peer review

- No space constraints or color figure charges

- Immediate publication on acceptance

- Inclusion in PubMed, CAS, Scopus and Google Scholar

- Research which is freely available for redistribution
Biomed Central 